\title{
The Origin and Growth of Peirce's Ethics
}

A Categorical Analysis

Rachel Herdy

\section{(2) OpenEdition}

Journals

Electronic version

URL: http://journals.openedition.org/ejpap/1060

DOI: 10.4000/ejpap. 1060

ISSN: 2036-4091

Publisher

Associazione Pragma

\section{Electronic reference}

Rachel Herdy, "The Origin and Growth of Peirce's Ethics », European Journal of Pragmatism and American Philosophy [Online], VI-2 | 2014, Online since 24 December 2014, connection on 30 April 2019. URL : http://journals.openedition.org/ejpap/1060 ; DOI : 10.4000/ejpap.1060

This text was automatically generated on 30 April 2019

\section{(c) $($ ) $\odot$ (8)}

Author retains copyright and grants the European Journal of Pragmatism and American Philosophy right of first publication with the work simultaneously licensed under a Creative Commons AttributionNonCommercial-NoDerivatives 4.0 International License. 


\title{
The Origin and Growth of Peirce's Ethics
}

\author{
A Categorical Analysis
}

Rachel Herdy

\section{AUTHOR'S NOTE}

The title of this paper is an allusion to Max Fisch's suggestion of the name Peirce might have given to his developmental study of Plato's ethics (Fish 1981: 30). Portions of this paper have been presented in a couple of forums dedicated to the study of pragmatism and Peirce's philosophy; and many people have helped me with their comments. I am grateful to the two anonymous reviewers for their valuable comments; and especially to Susan Haack who read and corrected many drafts.

What was it that Pascal said? "La vraie morale se moque de la morale."

(C. S. Peirce, 1902)

Charles S. Peirce's first account of ethics was enunciated in the second half of the 1890s, when he was almost sixty years old; and it was quite dismissive (CP 1.50, 1896). ${ }^{1}$ His second, positive view of ethics came shortly after (CP 8.158, 1901). The fact that it took Peirce many years to write about ethics and that he changed his mind in a relatively short period of time perhaps explains why his moral writings have not been taken seriously. ${ }^{2}$ This picture, however, has been recently challenged by a group of scholars who developed a growing interest in Peirce's normative thinking. ${ }^{3}$

The purpose of this paper is to offer a distinct contribution to recent attempts to understand Peirce's normative thinking. I want to trace the growth of Peirce's thinking about ethics from dismissing it as a "useless" and "dubious" kind of knowledge to reviewing it as a major philosophical concern; and to illustrate my argument I will show how his conflicting positions appear to correlate with his theory of the categories. While a diachronic approach will be necessary to correct some efforts to resolve the 
inconsistencies in Peirce's moral theory, ${ }^{4}$ a categorical account is essential to perceive its inner coherence and to support the view that Peirce moved from a nominalist to a realist position in moral philosophy.

My argument is a sequel to Rosa Mayorga's (2012) recent suggestion that Peirce's dismissive remarks about ethics should not be disregarded as either contradictory or cynical. Accordingly, Peirce has been of two minds about ethics, and his initial negative account can be understood in light of his distaste for nominalism. Following Mayorga's suggestion will allow me to advance the idea and propose that Peirce has been (as usual) of three minds, for eventually he came to think that ethics in the last resort appeals to esthetics. ${ }^{5}$ However, as I will argue, one would be wrong to conclude that Peirce came to think of ethics as belonging to the category of Firstness. With the help of Peirce's diagram of the degenerate forms of Thirdness, I will attempt to discuss a rather complex, subcategorical account of what I shall call the "threefold" normative ideal. I want to suggest that a comprehensive account of the growth of Peirce's ethics requires looking not only at the three universal categories - Firstness, Secondness, and Thirdness - but also at the degenerate forms of these categories; particularly, at the degenerate forms of Thirdness. The relation between Peirce's normative thinking and the category of Thirdness in all its detail has been seldom explored. ${ }^{6}$

2 I will begin with a brief account of the origin of Peirce's interest in ethics back in the 1880s, and the reasons that might have led to his radical change of mind (Section 1). I will then trace the three stages I identify in the growth of his conceptions of ethics, and show how his different positions appear to correlate with his categories (Section 2). While the correspondence between Peirce's notions of "morality" and "Pure Ethics," on the one side, and the categories of Secondness and Thirdness, on the other, will become clearer, finding a place for "esthetics" in his categorical scheme will be a more complicated task. This difficulty has even led some commentators to propose the inclusion of a Fourth category. I will explore in the last part of my paper the degenerate forms of Thirdness (Section 3).

3 Needless to say, an exhaustive description of Peirce's theory of the categories and its degenerate sub-divisions, as well as of his evolving conceptions of ethics is not possible within the scope of a single essay. Still, I hope to show that his thinking about ethics evolved significantly; and that his final realist position should be understood in light of the degenerate forms of Thirdness.

\section{The Origin of Peirce's Ethics}

4 Looking back during the 1903 Harvard Lectures to the origin of his interest in ethics, Peirce twice mentioned the year 1883. He told us that at that point in time he began to read the works of the "great" moralists and the subject of ethics started to make an impression on him (CP 5.111, 1903). Yet Peirce admitted that in the 1880 s he was not ready to say that ethics was a normative science (CP 5.129, 1903). ${ }^{7}$

5 What seems to have boosted Peirce's interest in ethics back in the 1880s was a course he taught in 1883-84 at the Johns Hopkins University, dedicated to the study of the psychology of great men. ${ }^{8}$ One of the main purposes was to show that observations devoid of precision, such as the greatness of men, admit mathematical treatment. A further purpose was to show that feelings "do not, for the most part, differ extravagantly among 
different persons in the same environment" (CP 7.257, 1900). His Study of Great Men (W5: 26-106, 1883-84) included around 300 distinguished and historical people. Interestingly, Peirce identified three kinds of greatness in men: "feeling," in musicians, novelists, artists, poets, writers, dramatists, and actors; "action," in rulers, generals, statesmen, personalities, philanthropists, explorers, and lawyers; and "thought," in philosophers, mathematicians, physicists, moralists, reformers, linguists, religionists, inventors, biologists, and historians (W5: 35-8, 1883-84). These three kinds of greatness bear a resemblance not only to the categories, but also to the three normative sciences he would later on identify: esthetics, ethics, and logic.

6 A different account of the origin of Peirce's interest in ethics has been given by the editors of the Peirce Edition Project: "This was in connection with his research for the Century Dictionary, for which Peirce wrote hundreds of philosophical definitions, including the entries for 'ethics' and 'moral'" (EP2: 252, note 21). Indeed, with the dictionary project in mind, Peirce began to teach at the Johns Hopkins University a new course on "philosophical terminology" in the fall of 1883; and it is almost certain that both the dictionary project and the course on philosophical terminology influenced his later investigations on the "ethics of terminology" (CP $2.220 \mathrm{ff} ., 1903)$, which Max Fisch (1981: 30) suggested, "probably had something to do with Peirce's growing interest in ethics." But while there seems to be a chronological coincidence between Peirce's positive views of ethics in the 1900s and his ethics of terminology, I believe it was his interest in ethics that prompted an ethical consideration of terminology, and not the other way round. Moreover, even though by 1883 Peirce had already begun working in many definitions for the Dictionary, he would only write the entries for letter "E" in 1886 (W5: 388 ff., 1884-86). 10

7 Now, perhaps the most important event of 1883 was the publication of the long-awaited Studies in Logic, a book edited by Peirce - though his name did not appear on the title page - and produced by his students from Johns Hopkins, described as "Members of the Johns Hopkins University." This book was a result of Peirce's intensive work on logic, both as investigator and teacher. To be sure, Peirce hinted at the significance of ethics to logic in a syllabus of sixty lectures on logic, written in the summer of 1883 , where he explicitly referred to "a close connection between logic and ethics" (W4: 476, 1883). Two peculiarities in Peirce's writings about logic at this time are worth mentioning: first, his emphasis on the practical side of logic - that is, "to teach us how to reach the truth"; second, his characterization of reasoning as a voluntary operation, so that "we may say that it [logic] is the art of reasoning rightly, or that it is a science which centres [sic] about this art" (W4: 400-1, 1883). Here Peirce takes for granted the notion of "selfcontrol" as a fundamental aspect of logical reasoning, which later on determined his reevaluation of ethics. However, he was still far from reaching his mature position.

8 This is clear in a letter he wrote to his former student Christine Ladd-Franklin in 1902, when she came to lecture on logic at the Johns Hopkins. Peirce regretted his crude opinions about ethics in the 1880s:

My dear Mrs. Franklin: It gives me joy to learn that you are to lecture on logic at the Johns Hopkins. But, oh, you will not have such a wonderful and charming class as I had, especially the first year. In those days I knew very little about logic, and did not even thoroughly understand upon what logic is based. I was not in possession of the proof that the science of logic must be based on the science of ethics, although I more or less perceived that sound reasoning depends more on sound morals than anything else. (Apud Ladd-Franklin, 1916: 715-22) 

not yet convinced about the connection between logic and ethics. I suspect an important inkling of his change of mind occurred around 1896-97. ethics. Indeed, it is hard to be sure, for his own remarks about it fluctuated: in 1903 Peirce assumed that until around 1899 he was "not prepared to affirm that ethics was a normative science" (CP 5.129, 1903); but in 1902 he declared that it was until around 1897. (CP 2.198, 1902) This latter account seems quite inconsistent with his 1898 suspicion of ethics (CP 1,618 ff., 1898). Moreover, around 1905 he told us that it was during the Lowell Lectures (delivered in the end of 1903) that he first asserted that logic was to be based upon ethics (CP 5.333, c. 1905); but this account does not seem to square either, for Peirce had written extensively about the normative sciences in his 1901-02 manuscripts of the Minute Logic.

11 According to Richard Robin (1964: 271), "Peirce's views on the normative sciences did not 'come out of the blue'." Peirce's mature consideration of norms and values is an extension of his theory of inquiry. Manley Thompson (1963: 195) agrees: "Truth as the goal of scientific inquiry is thus a phase of the summum bonum, a phase of the final end of all human action." In a similar direction, Christopher Hookway (1997: 202) suggests that one might see Peirce's late insistence on ethics as a result of his attempt to "provide a unified model of self-control, and hence of rationality." Murray Murphey (1993: 361) notes that as early as 1893 Peirce had already asserted that logical reasoning was a controlled operation of thought; and from then on, the recognition that logic was a normative science was only a step. However, as Murphey adds, at this point Peirce had also been influenced by his psychological work undertaken in conjunction with Joseph Jastrow back in the 1880s, as well as and by the publication of William James' book, The Principles of Psychology (1890): "It was also James' doctrine that the truth is a species of the good which suggested to Peirce the idea of the dependence of logic on ethics."

David Elmer Pfeifer (1971: 66) suggests that the elements for a discussion of ethics were already present in the Monist papers, published in 1892-3, where Peirce introduced the ideas of absolute chance (tychism), continuity (synechism), and evolutionary love (agapism). In these papers, Peirce discussed the notion of an end, which raised the question of value: "Although Peirce does not discuss an ultimate end...we are at the point where the kinds of considerations, which may lead directly to normative science and the summum bonum, are present." Also, "another possible source of Peirce's reevaluation of Ethics," Edward Petry (1992: 681) believes, "is his study of the writings of Johann Friedrich Herbart, whose division of the normative sciences was referred to in a manuscript just before his reevaluation (MS 400)." Fisch (1981: 30) argues that a more "decisive event" was Peirce's application of Wicenty Lutoslawski's "method of stylometry" to Plato's ethics. Lutoslawski (1897) applied statistical analysis to his observations of the peculiarities in the style of Plato's writings; and Peirce decided to apply Lutoslawski's method to his study of Plato's ethics. In his Minute Logic Peirce devoted approximately 125 pages to discuss Plato's dialogues, and this undertaking seems to be related to his interest in ethics (CP 1.584 , note 1$).^{12}$

To the above, I want to add another possible explanation. I suspect the recognition of real possibilities among other factors usually accepted by Peircean scholars prompted the growth of his conception of ethics. ${ }^{13}$ Robert Lane's (2007) study has shown that until 1896-97 Peirce held the idea that the "possible" could only be identified in terms of a 
concrete "state of information"; that is, in terms of the existent state of information of an actual speaker. Hence, "it is possible that p" meant that "in the present state of information, it is not known to be false that p." However, in the end of 1896 Peirce began to see that the "possible" might also be defined in terms of an "Ideal World," a kind of Platonic universe. As Peirce wrote: "a possibility remains possible when it is not actual," because the possible is not "what the actual makes it to be" (CP1.422, 1896). This is the great error of the nominalist schools, Peirce argues; namely, "that the quality of red depends on anybody actually seeing it." The universe of real possibilities is not determined by the existing world, but belongs to an Ideal World, i.e. a world that ought to be.

This explanation seems chronologically plausible in view of the development of Peirce's effort to establish a classification of the sciences in the last decade of the nineteenth century. The marginal place he attributed to ethics in his classificatory scheme started to undergo serious revisions in 1896-97, a period in which he made considerable changes in his classification. From 1892 to 1898 , Peirce attempted to draw at least ten different classificatory schemes; and in the manuscripts dated 1896 onwards (Kent 1987: 100), he ventured tentatively to incorporate ethics as a normative science among the divisions of Philosophy.

The above explanations do not exhaust the subject; besides, there seems to be no single event but a congeries of facts to account for Peirce's interest in ethics and his radical change of mind. I shall now turn to a developmental and categorical analysis of his different conceptions of ethics.

\section{The Growth of Peirce's Ethics}

\section{Phase 1: Morality and Secondness}

15 In a manuscript from 1896, "Lessons from the History of Science," Peirce declared that morality is essentially conservative, and that "conservatism about morals leads to conservatism about manners and finally to conservatism about opinions of a speculative kind" (CP 1.50, 1896). So, for the sake of good reasoning, to avoid what Peirce called "sham" or "make-believe" reasoning, ethics and philosophy were to be regarded as two distinct disciplines. Ironically, as Cornelis de Waal (2012: 89) observes, at this point Peirce's "ethics of inquiry seems to preclude ethical inquiry."

Peirce said in 1896:

In short, as morality supposes self-control, men learn that they must not surrender themselves unreservedly to any method, without considering to what conclusions it will lead them. But this is utterly contrary to the single-mindedness that is requisite in science. (CP 1.57, 1896)

17 It is surprising that at this point Peirce rejected the science of ethics on the basis of selfcontrol, for not only had he affirmed in the 1880s that logical inferences were voluntary and controlled operations of thought, and thus could be subject to criticism and classified as good or bad (W 4: 401, 1883); but he repeated this same idea in a manuscript written around 1893 (CP 7.444, 1893). Moreover, the notion of self- control would influence his decisive conclusion that logic rests on ethics, as well as his hesitation about including esthetics among the normative sciences. 

negative arguments about ethics. He denounced the belief that progress in philosophy naturally affects moral culture. Peirce confessed to standing in this respect as "a scientific man, condemning with the whole strength of conviction the Hellenic tendency to mingle philosophy and practice" (CP 1.618, 1898). Ethics was described as a "conservative," "dubious," "wretched," and "positively dangerous" subject. Peirce proceeded by drawing a sharp line between reasoning, as the distinctive feature of philosophical and scientific inquiry, and instinct or sentiment, as the source to which one should look in deciding matters of vital importance, such as moral and religious issues. no direction to human conduct. Recall Peirce's words in 1877: "The feeling of believing is a more or less sure indication of there being established in our nature some habit which will determine our actions. Doubt never has such an effect" (CP 5.371, 1877). Hence, when it comes to moral and vitally practical affairs, as opposed to science, one must be capable of action; and "the principle upon which we are willing to act is a belief" (CP 1.636, 1898). But if reasoning requires a man to be ready to abandon his beliefs, as Peirce affirmed, it follows that reasoning as such is detrimental to moral conduct. In 1896 Peirce explained:

If a proposition is to be applied to action, it has to be embraced, or believed without reservation. There is no room for doubt, which can only paralyze action. But the scientific spirit requires a man to be at all times ready to dump his whole cart-load of beliefs, the moment experience is against them. (CP 1.55, 1896)

21 Peirce had in mind the moral standards of the gentlemen that were in direct opposition to the ideas of freedom and public spirit, which were required for the existence of a scientific community (CP 1.673, 1898). Perhaps this explains Peirce's apology to "conservative sentimentalism," which should be understood as a form of irony (CP 1.662, 1898). It is inevitable not to see a taste for irony in these passages. Conservative sentimentalism meant not trusting to reasoning in matters of vital importance - and this is exactly what the conservative gentlemen did not do under the rubric of "conservatism." Peirce calls for an opposite meaning under the same rubric, and this is his chief irony. While conservative gentlemen proclaim the subordination of sentiments to individual reason, a conservative sentimentalist like Peirce, conversely, rates his individual reason modestly and proclaims the subordination of reason to sentiments (CP $1.634,1898)$.

It is important to note here that "sentimentalism" is an ambiguous term. Roughly, "sentimentalism" can mean trusting human's altruistic sentiments against natural selfishness; but it can also mean that passions have a primordial, overriding role against reasons - the latter is the view adopted by David Hume and his followers. Peirce was certainly a sentimentalist in the first sense, but not so clearly in the second sense (W 8: 188-9, 1892). In respect to the first sense, altruism is a theme present in Peirce's philosophy as early as the second half of the 1860 s, and it is the fundamental argument he 
articulated to explain the validity of the logic of science. Meaning resides not on what can be interpreted by a conscious individual, but on what can come to be connected to an interpretant in subsequent thoughts (W 2: 323, 1865). Peirce corrected Descartes' analysis of cognition as conscious intuition by showing that thought cannot be valid in subjective, individual, singular episodes. Thought calls for a sequence of inferences; therefore, "nothing which can happen to a man's self should be of more consequence to him than everything else. He who would not sacrifice his own soul to save the whole world, is illogical in all his inferences, collectively" (W 2: 270, 1869). ${ }^{14}$ At this juncture, Peirce saw ethics and philosophy as belonging to "radically foreign" departments. As Kent (1987: 106) notes, in 1898 "it is evident that Peirce had not yet made any attempt to bring logic and ethics together under the umbrella of the normative sciences." Ethics was a branch of Practical Science, almost an affair of Art, a subject completely devoid of any scientific character, whereas Philosophy was a branch of Theoretical Science:

Philosophy seems to consist of two parts, Logic and Metaphysics. I exclude Ethics, for two reasons. In the first place, as the science of the end and aim of life [ethics] seems to be exclusively psychical, and therefore to be confined to a special department of experience, while philosophy studies experience in its universal characteristics. In the second place, in seeking to define the proper aim of life, ethics seems to me to rank with the arts. (RLT 115-6, 1898)

This brings me to my central question. Peirce's first mind about ethics (or better, morality) appears to be related to his category of Secondness; and this apparently explains why he would not regard ethics as an important topic (Mayorga, 2009: 69). As Peirce tells us, the category of Secondness consists of the actual facts that are present in the concrete world. The experiences that fall under the category of Secondness are individuals, in the sense that they insist in being here and now "irrespective of any reason," or general law (CP 1.434. 1896). A Second is a brute fact, and it will remain contingent and accidental until any reason enters and serves as a Third mediator. The manifestation of Secondness is most prominent in the ideas of struggle, action, reaction, shock, constraint, volition, action, inhibition, effort, aggressiveness, brutality, resistance, duality etc. It can be logically represented as a dyadic relation, where two elements are brought in connection arbitrarily; that is, with no reason or mediating third.

For the present purpose, the most important character that the individuality of Secondness implies is that the individual "is determinate in regard to every possibility" (CP 1.435, 1896). Peirce calls this the principle of excluded middle: "Those objects of the universe which do not possess a given character possess another character which, in reference to that universe, is in the relation of negation to the first" (CP 1.450). Thus, the distinctions that apply to a Second are always dualistic in nature (CP 1.330, 1894).

As Peirce wrote in 1896:

One of the worst effects of the influence of moral and religious reasonings upon science lies in this, that the distinctions upon which both insist as fundamental are dual distinctions, and that their tendency is toward an ignoring of all distinctions that are not dual and especially of the conception of continuity. (CP 1.61, 1896)

Peirce's notion of morality gives emphasis to concrete ideals of conduct, such as the positive moral standards of an individual or a given community. Positive moral standards are always concerned with dual distinctions: good and bad; right and wrong; authorized and prohibited; legal and illegal. It would be a nominalistic mistake to attribute any philosophical importance to individual, or idiosyncratic positive moral reactions (Mayorga 2012). Generality is the key feature that is absent in Peirce's first notion of 
morality, for the possible variations of ideals of conduct appear to be exhausted in a multitude of existing dualisms.

The 1898 Cambridge Conferences represented the last moment Peirce would publicly express his disparaging attitude toward ethics. Peirce's words were strong, and his sarcastic tone almost certainly had to do with his disagreements with William James about the vitality of the topic to be addressed..$^{15}$ Whatever the case may be I believe it is wrong to simply dismiss his arguments or even to try to conflate these passages with later extracts. Indeed, Peirce himself confessed his crude view about ethics in a letter to James written in November 25, 1902:

When I gave my Cambridge lectures I had not really got to the bottom of it or seen the unity of the whole thing. It was not until after that that I obtained the proof that logic must be founded on ethics. (CP 8.256, 1902)

\section{Phase 2: Pure Ethics and Thirdness}

Peirce's positive attitude toward ethics was enunciated in a 1901 review of a book on ethics written by Edward Mezes. Peirce described Mezes' work as a kind of "ethical anthropology," the study of what men consider to be moral, and he thinks that this is not the kind of study representative of what he now decided to call "Pure Ethics." Peirce insisted on favoring a conservative viewpoint in regard to morals, as he did in his Cambridge lectures in 1898, but at this time he contended that "in pure theory, especially in a theory of aims, conservatism is irrational and out of place" (CP 8.158, 1901). He wrote specifically that "logic rests on ethics to a degree that few are aware of"; that "ethics as a positive science must rest on observed facts"; and that "the only solid foundation for ethics lies on those facts of everyday life which no skeptical philosopher ever yet really called in question" (CP 8.158, 1901).

Peirce's new conception of ethics gained better expression in the 1902 manuscripts of Minute Logic. He admitted that for a long time ethics seemed to him to be "completely foreign to logic"; and that he doubted whether it was "anything more than a practical science, or Art" (CP 2.198). But in 1902 he told us that he was beginning to see the subtlety of ethics, for logic "can be of no avail until one knows what it is that one is trying to do, which is precisely what ethics has to determine" (CP 2.120, 1902). Ethics, in his new scenario, "affords a quite indispensable help to the understanding of logic" (CP 2.82, 1902). Peirce's logic reconsidered in the light of ethics looks like this:

Now logic is a study of the means of attaining the end of thought. It cannot solve that problem until it clearly knows what that end is. Life can have but one end. It is Ethics which defines that end [...]. Had I fully comprehended this great principle early in life, I should undoubtedly have been over-influenced by the moral spirit. (CP 2.198, 1902)

From 1902 onwards Peirce classified Pure Ethics as a Normative Science, a positive science that asserts positive truths, which result from categorical facts. "That truth and justice are great powers in the world is no figure of speech, but a plain fact to which theories must accommodate themselves" (CP 1.348, 1903).

Peirce assumes that Pure Ethics is a strictly theoretical subject and must not be confused with the practical discipline of morality. Pure Ethics is the study of what ought to be regarded as the nature of right conduct, the so-called summum bonum. Peirce stresses that its aim is not to provide a catalog of ideals for the classification of human conduct in the classes of right and wrong, a sort of "casuistic ethics." Underlying this problem is the task 
of establishing the nature of the categories of right and wrong (CP2.198, 1902). ${ }^{16}$ Pure Ethics can thus be identified with what present- day philosophers describe as "Metaethics," a branch of Moral Philosophy concerned with second-order ethical questions. ${ }^{17}$ Metaethics is contrasted with Normative Ethics, which deals with first-order questions such as "Should I give to famine relief?" or "Should I return the wallet I found on the street?" The second-order questions that Metaethics attempts to address refer to issues that are metaphysical, epistemological, phenomenological, psychological, etc.: "Do moral properties exist?" "Is there moral knowledge?" "Can we justify moral claims?" "Are moral qualities external?" "What psychological state expresses a moral judgment?"

31 Peirce's Pure Ethics was not intended to engage with practical questions. He insisted that Pure Ethics had no aspiration to guide human conduct: "It is only intended to be pure theory" (CP 5.125, 1903). Though I understand that pure and practical ethics can be discriminated, I do not believe it is correct to say that they can be completely separated, or dissociated; for the mere possibility of engaging with practical questions trades on metaethical considerations. Peirce's separation thesis should therefore be weakened. ${ }^{18}$ Contemporary theories of Normative Ethics disagree not just about what should be done in particular scenarios, but more fundamentally about why a specific course of action should be preferred; but in order for someone to engage in these first-order questions, it is requisite to assume a theoretical position in Metaethics that favors the view that these questions can themselves be answered in a justified way. In this sense, although Peirce's Pure Ethics is not intended to guide conduct, it has a certain priority over practical questions. I cannot prescind practice from theory; though I can abstract theory from practice. $^{19}$

In the beginning of 1903 Peirce advanced significantly in his thinking about the relation between logic and ethics in a series of lectures entitled "Pragmatism as a Principle and Method of Right Thinking," delivered at Harvard University. Parenthetically it may be worth noting that Peirce opened his lectures by confessing that his earlier philosophical views obstructed him from perceiving "the advantage of being well imbued with pragmatism in the conduct of life" (RLT: 109, 1903) - a reference to the title of his inaugural lecture in the 1898 Cambridge Conferences, "Philosophy and the Conduct of Life," where he dismissed ethics as useless science. Now the theme of the 1903 Harvard lectures gave Peirce the opportunity to review his version of pragmatism and relate it to his new conception of the normative sciences.

33 As a principle of logic, it would be wrong to interpret the Pragmatic Maxim as making meaning, which is the "intellectual purport" of concepts, lie in individual action. Peirce had no doubt that action is the upshot of belief, but the meaning of concepts could not be of an individual instance, for it would have to be general; more properly, "conditional general resolutions to act" (CP 5.403, note 3, 1906).

Until this period, Peirce did not regard logical reasoning as a controlled operation of thought. But now he sees the operation of drawing an inference as a deliberate and purposive action, for it involves an approval of the inference. Every reasoner has the purpose of attaining truth; consequently, he is always conscious of proceeding according to "patterns of right reasoning" (CP 1.606, 1903). The reasoner usually compares his inference with the general norms of right reasoning in a deliberate, critical, and selfcontrolled attitude. "Logic is the theory of self-controlled, or deliberate, thought; and as such, must appeal to ethics for its principles" (CP 1.191, 1903). There is a perfect 
parallelism between reasoning and moral conduct, and this happens to be so in virtue of the element of self-control. ${ }^{20}$

Peirce's "second mind" about ethics (or better, Pure Ethics) appears to be related to his category of Thirdness. Roughly, the Third category includes everything that is of the nature of a law and involves the ideas of generality and continuity. It requires the human mind as a "subject foreign to mere individual action" where cognition takes place (CP $1.420,1896)$. In the logic of relations, the idea of a law presents itself as a triad, since it involves a third element that mediates between two other elements, a first and a second; and its mode of being, "consists in the Secondness that it determines" (CP 1.536, 1903). Thirdness belongs to a world of necessity; it is "how an endless future must continue to be" (CP 1.536, 1903).

Pure Ethics is related to the category of Thirdness because it is not concerned with individuality, understood as concrete ideals of conduct (morality), but with generality, understood as habits of conduct. Peirce is not interested in action per se, which belongs to the domain of Secondness, as explained in the previous section, but rather in the "governing," "mediation," or "self-control" of human action:

[The] pragmaticist does not make the summum bonum to consist in action, but makes it to consist in that process of evolution whereby the existent comes more and more to embody those generals [...]. In its higher stages, evolution takes place more and more largely through self-control, and this gives the pragmaticist a sort of justification for making the rational purport to be general. (CP 5, 433, 1905)

The point here, which Peirce advanced in the 1903 Lowell Lectures and after, is that the ultimate ideal lies in the process of self-control, the development of what he called "concrete reasonableness" (CP 5.3, 1902). ${ }^{21}$ Peirce can now see beyond the dualisms that characterize positive morality - they are mere fragments of the process of self-control. Continuity is the key notion in his procedural picture of Pure Ethics. Peirce now sees an element of generality in ideals of conduct because he does not take them to be a fragment of a continuous process, but the continuous process itself; i.e. ideals of conduct are seen as relations of ideals of conduct. When Pure Ethics is procedurally understood in light of Peirce's idea of continuity, the role of generality becomes clearer.

To sum up, I recall again Peirce's words:

I have advanced my understanding of these categories much since Cambridge days; and can now put them in a much clearer light and more convincingly. The true nature of pragmatism cannot be understood without them. It does not, as I seem to have thought at first, take Reaction as the be-all, but it takes the end-all as the beall, and the End is something that gives its sanction to action. It is of the third category. (CP 8.256, 1902; emphasis added)

\section{Phase 3: Esthetics and Qualitative Thirdness}

39 It was also in view of the controlled character of logic and ethics that Peirce would initially object to the inclusion of esthetics among the normative sciences: "that which renders logic and ethics peculiarly normative is that nothing can be either logically true or morally good without a purpose to be so," whereas "a thing is beautiful or ugly quite irrespective of any purpose to be so" (CP 1.575, 1902). What provoked his reconsideration of esthetics was the answer to the question of the ultimate end of conduct, the summum bonum. Peirce thought that the ultimate end of conduct would have to be an ideal that had a quality desirable in itself. Therefore, Peirce believed that it was the business 
neither of the logician nor of the moralist to decide the matter, for if the ultimate end were to be a quality, it was rather the business of the esthetician to decide (CP 2.199, 1902).

Now, "in the light of the doctrine of categories," Peirce wrote, "an object, to be esthetically good, must have a multitude of parts so related to one another as to impart a positive simple immediate quality to their totality" (CP 5.131, 1903). But a quality of feeling is specifically what best describes the category of Firstness. Should one thus interpret Peirce's assertion that esthetics is "the basic normative science upon which as a foundation the doctrine of ethics must be reared" $(\mathrm{CP} 5.37,1903)$ as an indication that he finally came to see ethics as a subject that belongs to the category of Firstness? Did Peirce at last approve a kind of ethical hedonism?

41 Peirce was quite distressed by this latter objection. The assumption that logic rests on ethics and ethics on esthetics would eventually lead to the conclusion that reasoning could be reduced to a matter of taste; but most of all it meant the reducibility of truth, which is an affair of the Third category, to a quality of feeling, which is an affair of the First category - a reducibility that Peirce's theory of the universal categories was not willing to admit. So, in the course of his argument for pragmatism in the 1903 Harvard lectures Peirce was led to discuss the idea of reducing one category to another. The main target of Peirce's objection was the notion of Gefühl, or Feeling of Logicality, as proposed by the German logician Christopher Sigwart in the 1870s. To entertain this opinion was "to refer truth to the category of Quality of Feeling" (EP 2: 166, 1903). Peirce wanted to repel attacks upon his categories which assumed that "the idea of Reaction can be reduced to that of Quality of Feeling and that the idea of Representation to those of Reaction or Quality of Feeling taken together" (EP 2: 177, 1903). And I suspect it was this concern in particular which led him to explore during the Harvard lectures the degenerate forms of the categories (the topic of the next section).

42 To be sure, the notion of "esthetical goodness" constitutes perhaps the most enigmatic idea in Peirce's normative sciences. It is a quite complex notion, for Peirce did not equate it with a mere quality of feeling. "Esthetic enjoyment" should be regarded as a kind of "reasonable feeling," i.e. a feeling one can comprehend; a sort of "intellectual sympathy" (CP 5.113, 1903). Peirce himself recognized the complexity of his conception: "I do not succeed in saying exactly what it is, but it is a consciousness belonging to the category of Representation, though representing something in the Category of Quality of Feeling" (CP 5.1113, 1903).

43 To clarify the notion of esthetical goodness, it might be helpful to contrast it with Peirce's idea of the "percept," which he introduced at just about the same time as he came to regard the normative science of esthetics (CP 2.27, 1902). Peirce wrote that the percept is "a quality of feeling or sensation," which consists of "a single and undivided whole," and thus is related to the category of genuine Firstness (CP 7.625, 1903). The process through which the percept comes to mind is not under the control of thought; for "it silently forces itself upon me" (CP 7.621, 1903). Thus, the percept could never be pronounced as either good or bad. On the other hand, esthetical goodness is under the control of thought, or else there would be no point in classifying esthetics as a normative science. Hence, esthetical goodness, unlike the percept, cannot be equated to a First - though it has a component of Firstness, as every category of experience does..$^{22}$ Indeed, the notion of esthetical goodness is closer to that of "perceptual judgment," for it includes an 
element of Thirdness. The perceptual judgment happens the moment a percept is contemplated:

The great overshadowing point of difference is that the perceptual judgment professes to represent something [...]. This is a very important difference, since the idea of representation is essentially what may be termed an element of "Thirdness" [...]. In a perceptual judgment the mind professes to tell the mind's future self what the character of the present percept is. The percept, on the contrary, stands on its own legs and makes no professions of any kind. (CP 7.630, 1903)

The concept of the percept was then able to accommodate the experience of genuine Firstness, which might otherwise be thought to relate to esthetics.

The difficulty in finding a place for esthetics among Peirce's categories has raised

the question whether one should propose the inclusion of a Fourth category. Herbert W. Schneider (1952) was the first to present this argument. He assumes that, besides an abstract and formal conception of the normative ideal, there is another kind of value situation in Peirce's thinking, which he called "Importance." Accordingly, the notion of importance relates to the idea of "conscious satisfaction." This is a concrete value situation where satisfaction is felt, andthuscannot be related tothecategory of Thirdness, for it inevitably "retracts" to Firstness. So Fourthness, he argues, is not a substitute for Thirdness, but an addition to it. Schneider's words seem to reiterate Peirce's in the CP 5.113 passage above mentioned: Fourthness is "the peculiar satisfaction which accompanies an interest which is perfectly understood" (1952: 212). In a rejoinder to Schneider, Carl R. Hausman (1979) expresses a similar but more ambiguous position. Although he denies Schneider's call for a Fourth category, Hausman assumes that the three universal categories are insufficient to account for the role of esthetical value in Peirce's philosophy. Since esthetical goodness is a rather complex value notion that should not be confused with the category of Firstness, Hausman argues that it has to "function" as a Fourth category, without actually being one; that is to say, a Fourth element that is co-present and irreducible to the other categories. ${ }^{23}$

For my part, I think a full-scale account of the category of Thirdness is needed to repudiate the inclusion of Fourthness. Peirce did not equate value with esthetical goodness alone; but with a complex triadic structure that elicits not only the idea of beauty, but also the notions of right and truth. As I understand, Peirce argued for a threefold notion of the normative ideal, in which logic, ethics, and esthetics are equally identified with the category of Thirdness. Murphey confirms this interpretation:

That which seems to constitute the acme of beauty for Peirce is the Firstness of genuine Thirdness carried to the furthest extreme - that is to say, it is the quality arising from order, and the more developed the order the greater the beauty [...]. Now that order will be the result of laws or habits - Thirds which control the arrangement of the aggregate of Seconds. (Murphey, 1993: 363)

8 As I will explain, the fact that esthetical goodness is at the bottom of the hierarchy of the normative sciences has to be understood as a logical requirement necessitated by Peirce's theory of the categories - Firstness is the primary element of experience, the one element that can be prescinded from all categories.

In a relatively unknown passage, Peirce wrote:

[Esthetics is] the total unanalyzable impression of a reasonableness that has expressed itself in a creation. It is a pure Feeling but a feeling that is the Impress of a Reasonableness that Creates. It is the Firstness that truly belongs to a Thirdness in its achievement of Secondness. (MS 310.9, 1903) ${ }^{24}$ 


\section{The Threefold Ideal and the Degenerate Forms of Thirdness}

50 And so I come to my concluding remarks. I believe the degeneracy of the categories can shed light on the final stage of Peirce's understanding of ethics, where he proposed that both logical and moral goodness, which are Thirds, are somehow dependent upon esthetical goodness, which merely "appears" as a First. Briefly, the categories of Secondness and Thirdness can assume degenerate forms, in which their characters appear weak and disfigured (CP 5.70, 1903); and this weakness can sometimes lead us to confuse one category with another. In order to understand these degenerate forms, the prescindibility of the categories is a key idea.

51 "Prescission" 25 implies less than dissociation and more than distinction. It happens when one can hypothetically consider one category while deliberately neglecting the existence of another. It is a mere "supposition," where "exclusive attention" is given to one category in detriment of another. It means that one element can be detached, or abstracted from the other. But separation by prescission is not a reciprocal process, Peirce observed (EP1: 3, 1968). That is, one can deliberately suppose uncolored space, but not color without space. "While $A$ cannot be prescinded from $B, B$ can be prescinded from A." Categorically speaking, one can suppose a First without a Second, but not a Second without a First; or, in other words, Firstness can be prescinded from Secondness and Thirdness, and Secondness can be prescinded from Thirdness - but no Thirdness can be prescinded from Secondness and Firstness; and no Secondness can be prescinded from Firstness. Each category can only be prescinded, or supposedly detached from, the category that comes next. (It is not accidental that Peirce decided to name his categories Firstness, Secondness, and Thirdness - which are ordinal, not cardinal, numbers, indicating a hierarchy.)

Secondness and Thirdness are conceptions of complexity (CP 1.526, 1903). This means that the conception of the category of Secondness is that of an actual fact which requires the existence of two different objects: a first and a second - it involves a dyadic relation. The same applies to the conception of the category of Thirdness, for it involves the presence of three different elements: a first and a second that act in response to one another in virtue of a third - it involves a triadic relation. In contrast, the conception of the category of Firstness involves no other element beyond itself; it is a monad, which has an "Extremely Rudimentary Character" (CP 5.68, 1903). Hence, the degeneracy of the categories of Secondness and Thirdness, as opposed to the category of Firstness, derives specifically from the logical complexity implicated in dyadic and triadic relations. Consider the following:

Where you have a triplet you have three pairs; and where you have a pair, you have two units. Thus, Secondness is an essential part of Thirdness though not of Firstness, and Firstness is an essential element of both Secondness and Thirdness. Hence there is such a thing as the Firstness of Secondness and such a thing as the Firstness of Thirdness; and there is such a thing as the Secondness of Thirdness. But there is no Secondness of pure Firstness and no Thirdness of pure Firstness or Secondness. (CP 1.530, 1903) 

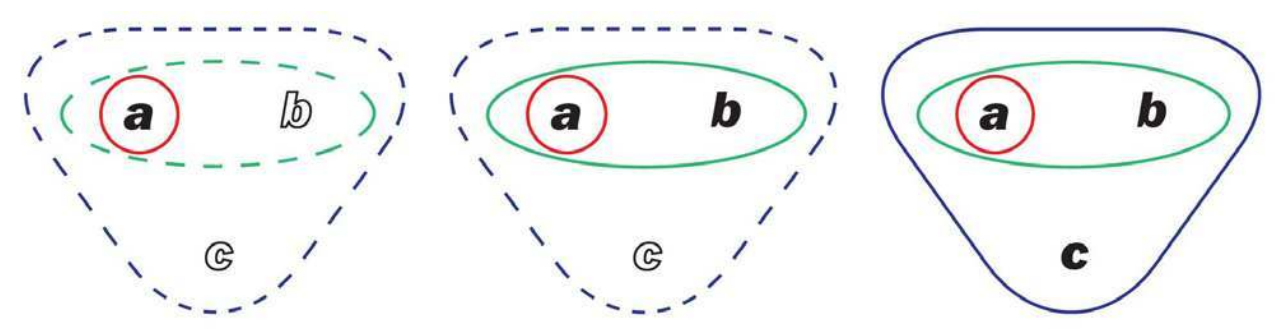

So, while Secondness can be expressed in two different ways, one genuine and another degenerate; and Thirdness can be expressed in three different ways, one genuine and two degenerate; the category of Firstness accepts no degeneracy. Let me draw a graphic representation of Peirce's explanation:

Fig. 1 Fig. 2 Fig. 3

Figures 1, 2, and 3 illustrate how Firstness can be prescinded from Secondness and Thirdness; how Secondness can be prescinded from Thirdness; how neither Secondness nor Thirdness can be prescinded from Firstness; and finally how Thirdness cannot be prescinded from Secondness. The number of bold characters ("a," "b," or "c") indicates the category to which each figure refers, and the bold borders highlight the degenerate forms that each category can assume. For example, in Figure 2 there are two bold characters, "a" and "b," indicating that it refers to the category of Secondness; and a bold border surrounds characters "a" and "ab," respectively, indicating that there are such degenerate forms of Secondness - the Firstness of Secondness and the Secondness of Secondness (Pure Secondness). Conversely, the dotted border surrounding the set comprised by "abc" in Figure 2 indicates that Thirdness cannot be prescinded either from Secondness or Firstness - there is no Thirdness of Secondness. So, in order to picture the degenerate forms of each category, one should focus on the bold letters and the bold borders.

For present purposes, I shall focus on Thirdness (Fig. 3). Peirce explains that the selfdevelopment of the category of Thirdness results in a trichotomy that gives rise to three sub-classes: "a relatively genuine thirdness, a relatively Reactional Thirdness or thirdness of the lesser degree of degeneracy, and a relatively Qualitative Thirdness or thirdness of the last degeneracy" (CP 5.72, 1903). However, as Peirce explains, the subsequent divisions will not entirely follow a trichotomy; they will divide in different ways. For instance, Reactional Thirdness will follow the manner of the divisions of the category of Secondness - it will divide in two; and Qualitative Thirdness will not divide at all. To illustrate these three divisions of Thirdness and its subsequent subdivisions, Peirce devised the following diagram (EP 2, 162, 1903): 


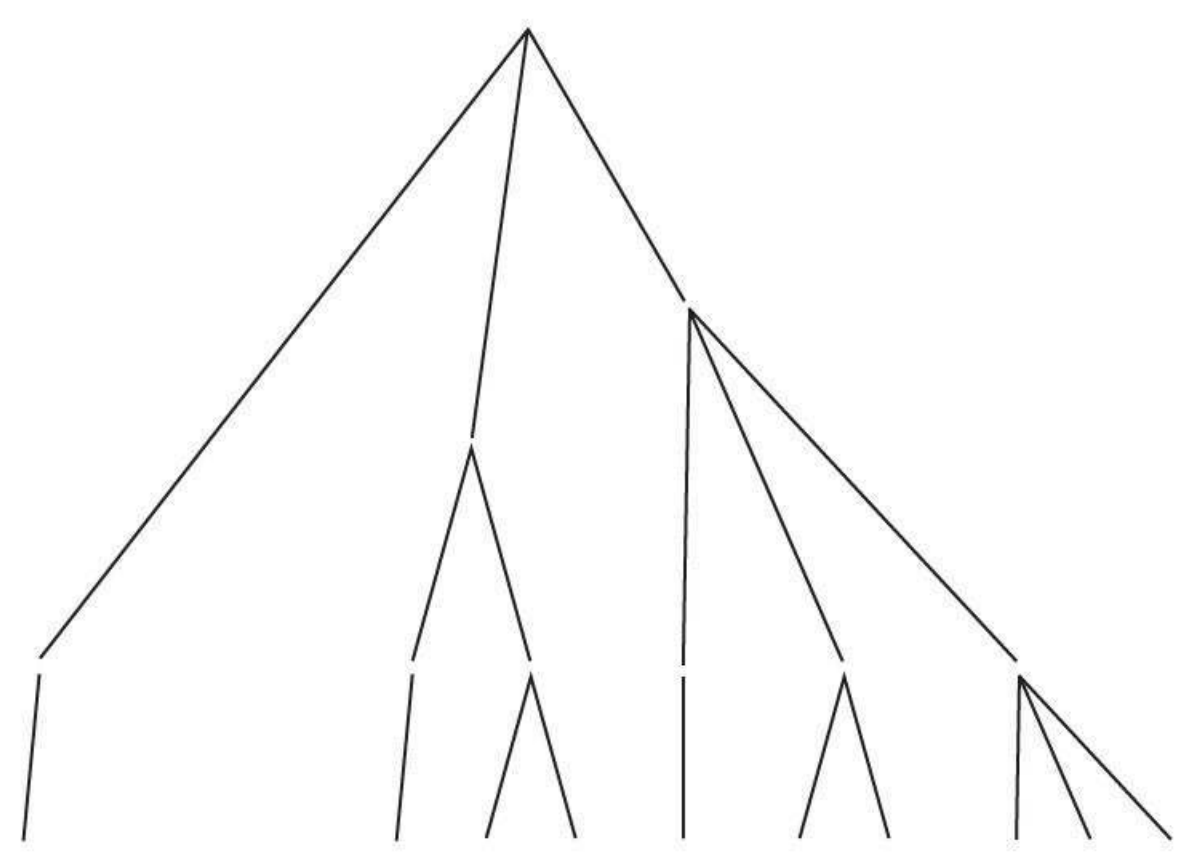

Two conclusions can be drawn from the diagram above: First, that the triad involves all three categories of experience, ${ }^{26}$ so there is always one leg of the triplet where the category of Thirdness is genuine; another leg where it is degenerate to a lesser degree, revealing its Secondness (Reactional Thirdness); and a third one where it is degenerate to a greater degree, revealing its Firstness (Qualitative Thirdness). This first conclusion is consistent with Peirce's assertion that Firstness, Secondness, and Thirdness must all be present in every phenomenon, "one being perhaps more prominent in one aspect of that phenomena than another" (CP 5.43, 1903). The second conclusion is that the only subdivisions that can be carried on ad infinitum are those of genuine Thirdness. These infinite subdivisions of the Third disclose an endless series of representational experiences that indicate the idea of continuity and illustrate Thirdness to perfection (CP $1.337,1875)$.

Qualitative Thirdness conveys the appearance that the Third category is from the world of feelings. Peirce calls this feeling an "instigation of thought"; an "embryonic being." Peirce explained:

The most degenerate Thirdness is where we conceive a mere Quality of Feeling, or Firstness, to represent itself to itself as Representation. Such, for example, would be Pure Self-Consciousness, which might be roughly described as a mere feeling that has a dark instinct of being a germ of thought. (CP 5.71, 1903) ${ }^{27}$

So now we can see that the normative ideal has a threefold dimension. In the line of the divisions of the Genuine Third one can relate it to the idea of true continuity (logic), and thus understand its evolutionary character (CP 5.3, 1902) - what is to be believed as the ultimate good in its genuine form will be defined by a future interpretant of the ideal, which in due course will require another future interpretant, and so on indefinitely until the Final Opinion is reached. This process is described as the growth of concrete reasonableness. This dimension of the normative ideal cannot be contracted in any individual; but more than that, it leads toward a reality unaffected by human perversity. Similarly, in the line of the divisions of the Reactional Third one can relate the normative 
ideal to the element of duality (ethics), for the growth of concrete reasonableness takes place in cognition through the exercise of self-control, or conscious inhibition; and it will usually fall into a catena, which discloses two opposing ways of thinking: right and wrong. And by picturing the conception of the normative ideal in the unitary line of the Qualitative Third one will sense an attractive instigation of thought (esthetics). ${ }^{28}$ Moreover, the hierarchy of the normative sciences and the fundamental place of esthetics can now be understood in terms of the prescindibility of the categories; and esthetics can be appreciated as a form of Qualitative Thirdness.

Thus, when Peirce affirmed that the central problem of the normative sciences comes down to a question of esthetics, he did not commit himself to some kind of hedonism, emotivism, or subjectivism, since he did not reduce the summum bonum to a mere feeling - otherwise, the normative interpretant would lack objectivity and Peirce would subscribe to some kind of ethical nominalism.

\section{Conclusion}

Studies about Peirce's normative thinking have either interpreted his contradictory positions as an attitude of rejection and sarcasm toward Moral Philosophy, or attempted to reconcile the inconsistent passages by erroneously taking a synchronic approach, thus missing the evolutionary character of his thought. Peirce changed his mind many times in his life, and in relation to many philosophical topics. It is not surprising that he also changed his mind about the notion of normativity and its place in his philosophy. This paper offered a distinct, diachronic and categorical contribution to understanding Peirce's normative thinking. More specifically, this paper advanced a sub-categorical analysis to understand the growth of Peirce's conceptions of ethics. While a diachronic approach was necessary to argue against the efforts to resolve the inconsistencies in his writings, a sub-categorical account was essential to support the view that Peirce moved from a nominalist to a realist position - not only in Metaphysics, but in Moral Philosophy too. By connecting Peirce's conceptions of ethics to his theory of the categories I hope to have provided a better understanding of the structure of his normative realism.

\section{BIBLIOGRAPHY}

ANDERSon D., (1999), "Peirce: Ethics and the Conduct of Life," in S. Rosenthal, C. Hausman, and D. Anderson (eds.), Classical American Pragmatism: Its Contemporary Vitality, Illinois, University of Illinois Press.

BERNSTEIN R. J., (1965), “Action, Conduct, and Self-Control,” in. R. Bernstein (ed.), Perspectives on Peirce: Critical Essays on Charles Sanders Peirce, New Haven and London, Yale University Press.

BOLER J. F., (1963), Charles Peirce and Scholastic Realism: A Study of Peirce's Relations to John Duns Scotus , Seattle, University of Washington Press. 
DE WAAL C., (2012), “Who's Afraid of Charles Sanders Peirce: Knocking Some Critical Common Sense into Moral Philosophy," in C. de Waal \& K. P. Skowronski (eds.), The Normative Thought of Charles S. Peirce, New York, Fordham University Press.

DEBRock G., (2001), “Las Categorias y el Problema de lo Possible en C. S. Peirce," translated by Sara F. Barrena, Anuario Filosófico, XXXIV, 1, 39-57.

DEMARCO J. P., (1973), "Peirce's Categories and Normative Inquiry," Journal of Value Inquiry, 7, 3, 214-6.

ESPOSITO J. L., (1981), “Peirce's Early Speculations on the Categories," in K. L. Ketner, J. M. Ransdell, C. Eisele, M. Fish, \& C. Hardwick (eds.), Proceedings of the C. S. Peirce Bicentennial International Congress (Graduate Studies Texas Tech University, n. 23), Lubbock, Texas, Texas Tech Press.

FISCH M., (1981), "Peirce as Scientist, Mathematician, Historian, Logician, and Philosopher," in K. L. Ketner, J. M. Ransdell, C. Eisele, M. Fish, \& C. Hardwick (eds), Proceedings of the C. S. Peirce Bicentennial International Congress (Graduate Studies Texas Tech University, n. 23), Lubbock, Texas, Texas Tech Press.

FISCH M., (1986), “Peirce's Arisbe: The Greek Influence in His Later Philosophy," in K. L. Ketner, \& C. J. W. Kloesel (eds.), Peirce, Semiotic, and Pragmatism, Bloomington, Indiana University Press. Hausman C. R., (1979), "Value and the Peircean Categories," Transactions of the Charles S. Peirce Society, 15, 3, 203-23.

HAUSMAN C. R., (1988), “Fourthness: Carl Vaught on Peirce's Categories,” Transactions of the Charles S. Peirce Society, 24, 2, 265-78.

Hookway C., (1997), "Sentiment and Self-Control," in J. Brunning, \& P. Forster (eds.), The Rule of Reason, Toronto, University of Toronto Press.

HOUSER N., (1993), “Introduction,” in C. Kloesel (ed.), Writings of Charles Sanders Peirce: A Chronological Edition, vol. 5. Bloomington and Indianapolis, Indiana University Press.

KENT B., (1976), “Peirce's Esthetics: A New Look," Transactions of the Charles S. Peirce Society, 12, 3, 263-83.

KENT B., (1987), Charles S. Peirce: Logic and the Classification of the Sciences, Kingston and Montreal, McGill-Queen's University Press.

KETNER K. L. \& H. PUTNAM, (1992), “Introduction: The Consequences of Mathematics," in K. L. Ketner (ed.), Reasoning and the Logic of Things: The Cambridge Conferences Lectures of 1898, Cambridge, Mass., Harvard University Press.

KING J. T., (1969), “A Peircean Thread in our Meta-Ethical Labyrinth,” Journal of Value Inquiry, 3, $113-25$.

KROLIKowsKi W. P., (1964), "The Peircean Vir," in E. C. Moore, \& R. S. Robin (eds.), Studies in the Philosophy of Charles Sanders Peirce, Second Series, Amherst, The University of Massachusetts Press. LADD-FRANKLIN C., (1916), “Charles S. Peirce at the Johns Hopkins,” The Journal of Philosophy, Psychology, and Scientific Methods, XIII, 26, 715-22.

LANE R., (2007), "Peirce's Modal Shift: From Set Theory to Pragmaticism," Journal of the History of Philosophy, 45, 4, 551-76.

LISZKA J., (2012), “Charles Peirce on Ethics," in C. de Waal, \& K. P. Skowronski (eds.), The Normative Thought of Charles S. Peirce, New York, Fordham University Press. 
LUTOSLAWSKI W., (1897), The Origin and Growth of Plato's Logic (With an Account of Plato's Style and of the Chronology of his Writings), London, New York, and Bombay: Longmans, Green, and Co.

MAYORGA R., (2009), “On Talisse's 'Peirceanist' Theory,” Transactions of the Charles S. Peirce Society, $45,1,65-70$.

MAYORGA R., (2012), "Peirce's Moral Realicism," in C. de Waal, \& K. P. Skowronski The Normative Thought of Charles S. Peirce, New York, Fordham University Press.

MILLER A., (2003), An Introduction to Contemporary Methaethics, Cambridge, Polity Press.

MISAK C., (2004), “C. S. Peirce on Vital Matters,” in C. Misak (ed.), The Cambridge Companion to Peirce , Cambridge, Cambridge University Press.

MULLIN R. P., (2007), The Soul of Classical American Philosophy: The Ethical and Spiritual Insights of William James, Josiah Royce, and Charles Sanders Peirce, Albany, State University of New York Press. MURPHY M., (1993), The Development of Peirce's Philosophy, Indianapolis/ Cambridge: Hackett Publishing Company.

PARKER K. A., (2002), “Charles S. Peirce on Esthetics and Ethics: A Bibliography," document available at: http://agora.phi.gvsu.edu/kap/CSP_Bibliography/.

PARret H., (ed.), (1989), Peirce and Value Theory: On Peircean Ethics and Aesthetics, Philadelphia, John Benjamins.

PEIRCE C. S., (CP), (1931-60), Collected Papers of Charles Sanders Peirce, edited by C. Hartshorne, P. Weiss, and A. Burks, 8 vols, Cambridge, The Belknap Press of Harvard University Press.

(EP), (1992-98), The Essential Peirce: Selected Philosophical Writings, ed. by N. Houser, C. Kloesel, and The Peirce Edition Project, 2 vols., Bloomington, Indiana University Press.

(RLT), (1992), Reasoning and the Logic of Things: The Cambridge Conferences Lectures of 1898, ed. by K. L. Ketner, Massachusetts, Harvard University Press.

(W), (1982-), Writings of Charles Sanders Peirce: A Chronological Edition, ed. by M. Fisch, C. Kloesel, and E. Moore, et al., 6 vols., Bloomington, Indiana University Press.

PETRY Jr. E., (1992), “The Origin and Development of Peirce's Concept of Self- Control,”

Transactions of the Charles S. Peirce Society, 28, 4, 667-90.

PFEIFER D. E., (1971), The Summum Bonum in the Philosophy of C. S. Peirce, PhD Dissertation, Graduate College of the University of Illinois at Urbana-Champaign.

POTTER V. G., (1997), Charles S. Peirce: On Norms and Ideals, New York, Fordham University Press.

ROBIN R. S., (1964), "Peirce's Doctrine of the Normative Sciences," in E. C. Moore, \& R. S. Robin (eds.), Studies in the Philosophy of Charles Sanders Peirce, Second Series, Amherst, The University of Massachusetts Press.

SCHNEIDER H. W., (1952), "Fourthness," in Philip P. Weiner, \& F. H. Young (eds.), Studies in the Philosophy of Charles Sanders Peirce, Cambridge, Harvard University Press.

THOMPson M., (1963), The Pragmatic Philosophy of C. S. Peirce. Second edition, Chicago, The University of Chicago Press.

VAught C. G., (1986), "Semiotics and the Problem of Analogy: A Critique of Peirce's Theory of Categories," Transactions of the Charles S. Peirce Society. 22, 3, 311-26. 


\section{NOTES}

1. References in this format are to Collected Papers of Charles Sanders Peirce, by volume and paragraph number, followed by the given year of the manuscript. Other references will follow the same notation: "EP" refers to The Essential Peirce: Selected Philosophical Writings; "W" refers to Writings of Charles Sanders Peirce: A Chronological Edition; and "RLT" refers to Reasoning and the Logic of Things: The Cambridge Conferences Lectures of 1898.

2. Richard Robin argued that Peirce was "too old and too feeble" to explore the subject (Robin 1964: 271); and Manley Thompson believed that the development of his thinking about ethics was "so slight as to make any detailed consideration of his fragmentary pronouncements on its problems seem singularly unpromising” (Thompson 1963: 197). Beverley Kent (1987: 220, note 35) disagreed: "That this was a later development in the evolution of Peirce's thought should enhance its significance rather than detract from it, because it represents his mature view."

3. See the 2012 collection of essays, The Normative Thought of Charles S. Peirce, edited by de Waal and Skowronski. For earlier works on the topic, see Bernstein (1965: 86); Anderson 1999; and Mullin 2007. For a previously valuable collection of essays, see Parret 1989; and for a comprehensive bibliography, see Parker 2002.

4. Scholars have interpreted the real tensions in Peirce's normative thought by conflating passages from different moments in the development of his philosophy. For instance, extracts from Peirce's 1898 lectures are frequently combined with later passages from 1902 onwards, when he changed his mind. See Cheryl Misak (2004: 174), James Liszka (2012: 78), and de Waal (2012: 90-1). Due to space limitations I cannot elaborate on more specific examples here.

5. Peirce used the term "esthetics" as a variant of "aesthetics."

6. James T. King (1969: 113-25) presents a "triadic" conception of ethics based on Peirce's category of Thirdness. His work does not explore Peirce's ethics, but focuses on a criticism of Moore's conception of the good. Commenting on King's paper, Joseph P. DeMarco points out how Peirce himself attempted to apply his categories to ethics, and reached the conclusion that Firstness of Thirdness is the key to ethics (1973: 214-6). In spite of my disagreements on some points, I share with these authors the recognition of the analytical value of Peirce's categories to his ethical theory. My goal is to advance a sub-categorical analysis to understand the growth of Peirce's ethics.

7. I note that in 1855 Peirce read Schiller's Aesthetic Letters (W 1: 2, 1855); and that in 1857 he wrote a brief commentary on Schiller's definition of beauty and its relation to morality and knowledge (W 1: 10-12, 1857). Another interesting point, noticed by Joseph Esposito (1981: 343), is that Peirce's early speculations on the categories appear to have been "inspired by Schiller's drive to reconcile sensation and thought, value and fact."

8. See Houser's “Introduction," in (W5: xxiii, 1993). Peirce's 1901 paper, “The Century's Great Men.

of Science," was related to this investigation (CP 7.256-66, 1900).

9. Fish (1986: 395).

10. Just for the record, 1883 was the year Peirce divorced his first wife Melusina and remarried (six days later) the mysterious Juliette, sailing to Europe three days afterwards; the year he was having personal problems at the Johns Hopkins, unsatisfied with his part-time position as a lecturer in logic; the year he attempted to buy back some of the books of his library, which had been sold three years before for the amount of $\$ 550.00$ to the Johns Hopkins; the year a serious dispute broke out concerning an alleged act of plagiarism of his Logic of Relatives committed by Professor Sylvester; and also the year John Dewey dropped out from his Logic course, because it 
was "too mathematical." For a complete account of Peirce's life and career during the years of 1879-84, see Houser's "Introduction," in W4: xix-lxx.

11. Esposito (1981: 344) mentions that at some point near the end of the 1850 s Peirce called his approach to metaphysics, "with great caution, the practical approach" (MS 920.5). And he adds the following: "I think here that Peirce, hardly in his twenties, had the brilliant insight that all consciousness, expression, and even creation are intentional in their very nature."

12. These manuscripts have not been published yet. I expected to find in these writings some answers to the questions I raise here; Thompson, however, anticipates that "the discussion does not seem to contribute anything which has not already been remarked" (1963: 198).

13. I have reached this hypothesis independently by reading Lane's work (2007); later I found this idea in Kent (1987: 194). Fisch (1986: 228) claims that toward 1899 Peirce recognized the reality of Firsts. It is beyond the limits of this essay to consider the complexities of Peirce's notion of real possibilities. However, an interesting question, which bears directly on my topic, is how real possibilities relate to the categories (Debrock 2001: 39-57).

14. Perhaps I should add that "conservatism" is also a quite ambiguous word - not to mention the fact that Peirce himself indiscriminately switched references between "conservative sentimentalism" and "sentimental conservatism." Roughly, "conservatism" has at least two senses: it can mean the tendency not to separate oneself from the past, history, community, institutions; but it has also been associated to individualistic political views that support minimal and liberal conceptions of State authority and free market economy. Peirce's notion of continuity was certainly conservative in the first sense, but he was clearly not a conservative in the second sense (see W 8: 192, 1892).

15. Peirce wanted to talk about logic, whereas James called for a more "popular plan," arguing that among his students there were "only three man who could possibly follow" the graphs. James, who had arranged the lectures for Peirce, asked him to "be a good boy" and modify his initial proposal (Apud, Ketner \& Putnam 1992: 25).

16. In his seminal work on the theme of ideals in Peirce's philosophy, Vincent Potter (1997 [1967]: 32) writes that Peirce regarded Pure Ethics as the study of what makes "right right and wrong wrong." Richard Robin identifies Peirce's definition as a distinct usage of the concept, which underlines not the valuation of concrete actions but the inquiry into the conditions for the satisfaction of human purpose: "the 'ought' is hypothetical" (Robin, 1964: 227).

17. A clear introduction to Metaethics can be found in Miller 2003.

18. I thank the anonymous reviewer of EJPAP for calling my attention to this point.

19. I am restating Peirce's considerations about the degrees of separability of ideas (EP 1: 2-3, 1898).

20. Recall that in 1896-98 Peirce had excluded ethics from the branch of philosophy based on the fact that the idea of self-control would block the way of inquiry.

21. Krolikowski (1964: 267) relates the infinite process of evolution with the continuing character of self-control as something that can be endlessly exercised.

22. One might say that these both notions - "percept" and "esthetical goodness" - have also a component of Secondness. They might be related to a Second because they seem to call for a separate other or being on which to work its quality. It seems a plausible conclusion, indeed. The "perceptual judgment" is indeed a Third, and therefore partakes of a Second - as I will explain in the next section. But one could argue that this cannot be true in relation the idea of a "percept." In view of Peirce's final and extreme form of scholastic realism, the reality of a genuine quality does not depend on any concrete, actual realization. Peirce rejects the contraction of Firsts to existent Seconds. This can be illustrated by his second formulation of the Diamond example, in which its "hardness" or "resistance to pressure" is determined not on the basis of any actual experiment, but on the basis of a possible experiment in an ideal world (CP 8.208, c.1905). For a discussion, see Boler (1963: 142ff.). 
23. For more on the topic, compare: Vaught (1986: 311-26); and Hausman (1988: 265-78).

24. I trust this citation to Beverley Kent's article, "Peirce's Esthetics: A New Look" (1976).

25. Peirce uses the noun "prescission" to refer to the verb "to prescind," which means "to abstract from" or to "dissect in hypothesis," as opposed to the word "precision," which means "an expression of determination" (CP 5.449, 1905).

26. See Kent (1987: 157) claiming that "such an ideal succeeds in incorporating all three of the Peircean categories."

27. Cf. CP 5.535, 1905.

28. See Peirce 2.34, 1902; 1.615, 1903.

\section{ABSTRACTS}

The purpose of this paper is to offer a distinct contribution to recent attempts to understand Peirce's normative thinking. Scholars have interpreted the real tensions in Peirce's normative thought by conflating passages from different moments in the development of his philosophy. Extracts from Peirce's famous 1898 lectures (when he dismissed ethics as useless) are frequently combined with later passages from 1902 onwards, when he changed his mind. This paper proceeds by tracing the growth of Peirce's thinking about ethics and correlating his conflicting positions with his theory of the categories. The approach offered here is diachronic. A diachronic approach is necessary to correct some efforts to resolve the inconsistencies in Peirce's moral theory. Also, a categorical account is understood as essential to perceive the inner coherence of his moral philosophy and to support the view that Peirce moved from a nominalist to a realist position in ethics. By connecting Peirce's conceptions of ethics to his theory of the categories I hope to have provided a better understanding of the structure of his normative realism.

\section{AUTHOR}

\section{RACHEL HERDY}

Universidade Federal do Rio de Janeiro

rachelherdy[at]direito.ufrj.br 